\title{
Effect of Organic Manures and Microbes on Striga asiatica (L.) Kuntze Management in Kodo Millet
}

\author{
Ruchi Chourasia $^{{ }^{*}}$ and A.K.Jain ${ }^{2}$ \\ ${ }^{1}$ School of Agriculture Science \& Technology, Sardar Patel University, Balaghat, M.P., India \\ ${ }^{2}$ Department of Plant Pathology, JNKVV, College of Agriculture, Rewa, M.P., India \\ *Corresponding author
}

K e y w o r d s
$\begin{aligned} & \text { Kodo millet, Striga } \\ & \text { asiatica, } \\ & \text { Management, } \\ & \text { Organic manures, } \\ & \text { Microbes }\end{aligned}$
Article Info
$\begin{aligned} & \text { Accepted: } \\ & \text { 20 July 2020 } \\ & \text { Available Online: } \\ & \text { 10 August } 2020\end{aligned}$

\section{Introduction}

Kodo millet (Paspalum scrobiculatum $\mathrm{L}$ ) is a hardy small seeded cereal crop, generally grown by poor farmers in low fertile lands with low or no cash inputs for their own consumption. The grains are nutritionally as well as medicinally rich and recommended for diabetic patients. In India, Madhya Pradesh ranks first in area of kodo millet, where the crop is cultivated in 143.47 thousand hectares with average yield of 525.5 $\mathrm{kg} \mathrm{ha}^{-1}$ (www.landrecords.mp.gov.in). Among the biotic stresses, partial root parasitic flowering plant, Striga species popularly known as witch weed is a major constraint and a serious threat to subsistence kodo millet production particularly in light and low fertile soils by withdrawal of water, nutrients and assimilates. Striga damage is associated with 
degraded environments and is most severe in subsistence farming system. In India, few species of Striga namely $S$. asiatica, $S$. hermonthica, S. lutea and S. densiflora were reported to cause devastating yield losses in coarse cereals particularly in kodo millet (Kumar, 1940, Jain and Tripathi, 2002), finger millet (Srinivasan, 1947), foxtail millet (Kumar and Solomon, 1941, Srinivasan, 1947), pearl millet (Kumar and Solomon, 1941, Porwal, 1975), sorghum (Sarmiso, 2016), maize (Gacheru and Rao, 2001). In a roving field survey, Striga incidence ranging from 0.0 to $17.5 \%$ with higher frequency of Striga infestation varied from 66.7 to $100.0 \%$ was recorded in 7 districts of Madhya Pradesh during the year 2005 to 2011 by Jain et al., (2016) in farmer's field. Resistance in kodo millet cultivars against Striga species were reported by Reddy and Dastagiraiah (1987) and Jain et al., (2018). Advance research on Striga control was reviewed by Teka (2014) and suggested that integrated Striga management strategies are the suitable approach against this noxious root parasite. Use of organic and inorganic fertilizers, AM fungi, herbicides and biological control has been recommended to reduce Striga damage in cereal crops. Hence, in the present investigation, attempts have been made to study the effect of organic manures and microbes on Striga asiatica (L.) Kuntze management in kodo millet.

\section{Materials and Methods}

A field experiment was conducted using two organic manures i.e. farm yard manure (FYM) and vermicompost (VC) along with three microbes namely Trichoderma viride, Azosprilillum spp. and Glomus intraradices (VAM) in various combinations at experimental area of College of Agriculture, Rewa (M.P.) during Kharif 2015. The experiment was laid out in randomized block design with three replications in a plot size of
$3.0 \times 1.5 \mathrm{~m}$ with $22.5 \mathrm{~cm}$ row to row and 7.5 $\mathrm{cm}$ plant to plant spacing. Striga sand mixture (1:39) was applied @ $15 \mathrm{~g} \mathrm{plot}^{-1} 10$ days before sowing of a susceptible Kodo millet variety GPUK 3. Microbes were mixed in FYM / Vermicompost (table 1), incubated for 15 days and then applied in the soil at the time of sowing.

Application of $100 \%$ recommended dose of fertilizers (RDF) along with two controls namely non-infested with Striga and infested with Striga were also maintained for comparison. Striga related parameters namely number of emerged Striga plant plot $^{-1}$ (NS), Striga vigour ratings (SVR), Striga severity (SS) and area under the above ground Striga number progress curve (ASNPC) were recorded in each plot at dough stage. SVR was scored per row on a scale of 0-9 depending on height and number of branches in Striga plant (Haussman et al., 2000).

Striga vigour rating (0- 9 scale)

\begin{tabular}{|l|l|}
\hline Grade & \multicolumn{1}{c|}{ Striga plant } \\
\hline 0 & $\begin{array}{l}\text { no emerged Striga plants } \\
\text { average height of Striga plants } 5 \\
\text { cm without branches, } \\
\text { average height of Striga plants } 6- \\
20 \mathrm{~cm} \text { without branches } \\
\text { average height of Striga plants } 6- \\
20 \mathrm{~cm} \text { with branches, } \\
\text { average height of Striga plants } 21- \\
30 \mathrm{~cm} \text { with } 5 \text { branches, } \\
\text { average height of Striga plants } 21 \\
-30 \mathrm{~cm} \text { with }>5 \text { branches, } \\
\text { average height of Striga plants } 31- \\
40 \mathrm{~cm} \text { with } 10 \text { branches, } \\
\text { average height of Striga plants } 31- \\
40 \mathrm{~cm} \text { with }>10 \text { branches, } \\
5\end{array}$ \\
6 & $\begin{array}{l}\text { average height of Striga plants } \\
40 \mathrm{~cm} \text { with } 10 \text { branches and } \\
\text { average height of Striga plants } \\
40 \mathrm{~cm} \text { with }>10 \text { branches }\end{array}$ \\
\hline 8
\end{tabular}


Striga severity (SS) was calculated for each treatment by multiplying number of emerged Striga plant with Striga vigour ratings (Rodenburga et al., 2005). Area under Striga number progress curve (ASNPC) is a measure of the total Striga emergence throughout the season in each treatment and was calculated as per formulae outlined by Haussman et al., (2000).

$$
\text { ASNPC }=\sum_{\mathrm{i}=0}^{\mathrm{n}-1}\left[\mathrm{Si}+\frac{\mathrm{s}(\mathrm{i}+1)}{2}\right](\mathrm{t}(\mathrm{i}+1)-\mathrm{ti})
$$

Where,

$\mathrm{n}$ is the number of Striga assessment dates, $\mathrm{Si}$ is the Striga number at $i^{\text {th }}$ assessment date and $\mathrm{Ti}$ is the days after sowing at $\mathrm{i}^{\text {th }}$ assessment.

Yield and yield contributing traits namely plant height $(\mathrm{cm})$, leaves plant $^{-1}$, leaf area $\left(\mathrm{cm}^{2}\right)$, panicles weight plant ${ }^{-1}(\mathrm{~g})$, and fresh weight as well as dry weight of kodo millet plant was recorded in each treatment. Grain yield plot $^{-1}(\mathrm{~g})$ was recorded at maturity and converted into $\mathrm{kg} / \mathrm{ha}$. Relative grain yield increment (GYI) over control was calculated using the following formula.

$$
\text { GYI }(\%)=\frac{\begin{array}{l}
\text { Grain yield } \\
\text { in a treatment }- \text { in control }
\end{array}}{\text { Grain yield in control }}
$$

The data were analyzed statistically in randomized block design using software WASP-1. The treatments were compared by least significant differences at $5 \%$ probability levels.

\section{Results and Discussion}

The results pertaining to the effect of organic fertilizers enriched with Trichoderma, Azospirillium and Glomus intraradices (VAM) along with inorganic fertilizers on Striga related parameters, yield contributing traits and grain yield are presented in Table $1 \&$ Table 2.

\section{Striga related parameters}

Data presented in Table 1 related significant difference in emerged Striga count per plot (NS) in different treatments ranging from 0.0 to 20.0 with an average of 16.7 . Minimum NS was recorded in application of 100 per cent RDF (T9) i.e. 40:20:0 Kg NPK per hectare (10.3) followed by application of FYM (2.5 t per hectare )+ vermin-compost (1.25 $\mathrm{t}$ per hectare) enriched with Trichoderma + Azospirillum @ $2 \mathrm{Kg} /$ tones of manure (T7), application of FYM $\left(2.5 \mathrm{t} \mathrm{ha}^{-1}\right)+\mathrm{VC}(1.25 \mathrm{t}$ $\mathrm{ha}^{-1}$ ) enriched with Trichoderma @ $2 \mathrm{~kg}$ /tones of manure (T5), vermi-compost (VC) @ 2.5 t/ha enriched with Trichoderma@2 kg/tones of manure (T3) and application of VC@ 2.5 t/ha enriched with Glomus intraradices (T8). Reduction in NS ranged 60.2 to $79.5 \%$ was maximum in $\mathrm{T}_{9}$ followed by $\mathrm{T}_{7}$ and $\mathrm{T}_{5}$. Striga severity (SS) ranged 0.0 to 280.8 in different treatments. Lowest $\mathrm{SS}$ was noted in $\mathrm{T}_{7}$ followed by $\mathrm{T}_{9}, \mathrm{~T}_{5}$ and $\mathrm{T}_{3}$. Reduction in $\mathrm{SS}$ was 70.6 to $92.2 \%$ in different treatments. Maximum reduction in SS was recorded in $\mathrm{T}_{7}$ closely followed by $\mathrm{T}_{9}$ and $\mathrm{T}_{5}$. Striga vigour ratings (SVR) ranged 0.0 to 5.4 in various treatments. Lowest SVR was recorded in $\mathrm{T}_{7}$ followed by $\mathrm{T}_{9}$. Values of area under Striga number progress curve (ASNPC) varied 0.0 to 428.0 in different treatments was minimum in $\mathrm{T}_{7}$ (147.0), followed by $\mathrm{T}_{9}$ (151.3) and $\mathrm{T} 5$ (154.2). Overall, Striga related parameters were lowest in $\mathrm{T} 7$, closely followed by $\mathrm{T}_{9}$ and $\mathrm{T}_{5}$. These treatments were found to reduce the Striga infestation in Kodo millet.

\section{Yield and yield contributing traits}

The results of grain yield and its contributing traits presented in Table 2 revealed significant variation in plant height $(\mathrm{cm})$, leaves plant $^{-1}$, leaf area $\left(\mathrm{cm}^{2}\right)$, panicle weight plant ${ }^{-1}$, fresh 
weight and dry weight of kodo millet plant among the treatments. Plant height varied from 36.7 to $47.5 \mathrm{~cm}$ was maximum in application of 100 per cent RDF (T9) and was at par in all the treatments except control noninfested with Striga (T10) and application of vermicompost (VC) @ $2.5 \mathrm{t} / \mathrm{ha}$ enriched with Azospirillum @ $2 \mathrm{~kg} /$ tones of manure $\left(\mathrm{T}_{4}\right)$. Leaves plant $^{-1}$ varied 11.7 to 18.6 with maximum number in $\mathrm{T}_{7}$ closely followed with $\mathrm{T}_{6}, \mathrm{~T}_{5}, \mathrm{~T}_{9}$ and $\mathrm{T}_{8}$. Leaf area (LA) was significantly influenced and ranged 16.8 to $24.5 \mathrm{~cm}^{2}$ in different treatments. Maximum LA was estimated in $\mathrm{T}_{9}$, which was at par in $\mathrm{T}_{7}, \mathrm{~T}_{5}, \mathrm{~T}_{6}$ and $\mathrm{T}_{8}$. Panicle weight plant $^{-1}$ ranging from 3.02 to $4.82 \mathrm{~g}$ was highest in $\mathrm{T}_{5}$ followed by $T_{7}, T_{9}$ and $T_{3}$. Fresh weight and dry weight of kodo millet plant was recorded highest in $\mathrm{T}_{7}$ and were at par in $\mathrm{T}_{9}, \mathrm{~T}_{8}$ and $\mathrm{T}_{5}$. Grain yield $\left(\mathrm{kg} \mathrm{ha}{ }^{-1}\right)$ of kodo millet in different treatments ranged from 663.0 to $1022.2 \mathrm{~kg} \mathrm{ha}^{-1}$. It was highest in $\mathrm{T}_{7}$ and statistically at par in the treatments of $\mathrm{T}_{9}, \mathrm{~T}_{6}$, $\mathrm{T}_{5}, \mathrm{~T}_{3}$ and $\mathrm{T}_{8}$. An increase of 12.8 to $54.2 \%$ in grain yield was recorded in different treatments. Maximum grain yield increment over control was recorded in application of FYM $\left(2.5 \mathrm{t} \mathrm{ha}^{-1}\right)+\mathrm{VC}\left(1.25 \mathrm{t} \mathrm{ha}^{-1}\right)$ enriched with Trichoderma + Azospirillum @ 2 $\mathrm{kg} /$ tones of manure $\left(\mathrm{T}_{7}\right)$ followed by application of $100 \%$ RDF $\left(\mathrm{T}_{9}\right)$.

Organic manures contain high amount of nitrogen that could be used to reduce Striga infestation by the mechanisms of reduction in stimulant exudation from host roots. Esliba et al., (2000) reported that a combination of 40 kg N ha ${ }^{-1}$ and FYM @ 10, 20 and $30 \mathrm{t} \mathrm{ha}^{-1}$ reduced Striga emergence and improved grain yield as compared to control in sorghum and maize. Dzomeku and Amegbor (2013) reported $80 \%$ suppression in emergence of $S$. hermonthica infesting maize by using organic manure and neem powder. Osman et al., (2013) observed reduced emergence of $S$. hermonthica infecting maize in the treatment of organic fertilizers EIkhairat (mixture of plant residues) and EIkhaseeb (mixture of sheep manure, FYM and chicken in 1:2:1 ratio) alone and enriched with phosphorin (Bacillus megatherium var. phosphacticum). However, application of Azospirillum brazilence with organic fertilizers was not found effective to reduce Striga emergence. Effectiveness of Tichoderma harzianum and T. viride was reported against phanerogamic root parasites like Striga (Hassan et al., 2013 and Boari et al., 2016) and orobanche (Abdel kader and EI- Mougy, 2009). Boari et al., (2016) reported that $T$. harzianum and Fusarium oxysporum reduces the strigalactone (SL) content, which is responsible for Striga seed germination. These microorganisms act as a physiological barrier by preventing the germination of Striga seeds through the ability to biotransform the stimulatory signals. Contribution of AM fungi play key ecological role in nutrient acquisition, disease prevention and soil aggregate formation. Gworgwor and Weber (2003) reported that AM fungi Glomus mosseae significantly reduced the number of Striga emerging plant (S. hermonthica), increased plant growth, shoot and total dry matter and yield of sorghum. Maximum root colonization of sorghum by AM fungi was in G. mosseae (44\%) and G. intraradices (24\%). Lendzemo et al., (2005) also suggested that Striga performance in the presence of AM fungi was negatively impacted with reduced and / or delayed germination and attachment with the host roots. Significant reduction in the number of $S$. hermonthica shoot in sorghum (> 50\%) and maize (30\%) along with dry weight of Striga with AM fungal inoculation was recorded. Othira et al., (2012) also reported that AMF (Glomus spp.) inhibit the germination and reduces the growth of $S$. hermonthica, where as enhance the growth and development of maize. All these reports corroborate the present findings. 
Table.1 Striga related parameters as influenced by organic fertilizers and microbes in kodo millet

\begin{tabular}{|c|c|c|c|c|c|c|c|}
\hline $\begin{array}{l}\text { Treatmen } \\
\text { t Code }\end{array}$ & Treatment details & $\begin{array}{c}\text { Striga } \\
\text { count plot }^{-1} \\
\text { (NS) }\end{array}$ & $\begin{array}{l}\text { Relative } \\
\text { reduction } \\
(\%) \text { in NS }\end{array}$ & $\begin{array}{c}\text { Striga } \\
\text { severity } \\
\text { (SS) }\end{array}$ & $\begin{array}{c}\text { Relative } \\
\text { reduction } \\
(\%) \text { in SS }\end{array}$ & $\begin{array}{c}\text { Striga } \\
\text { vigour } \\
\text { rating } \\
(0-9)\end{array}$ & $\begin{array}{l}\text { Area under } \\
\text { Striga number } \\
\text { progress curve } \\
\text { (ASNPC) }\end{array}$ \\
\hline $\mathbf{T}_{1}$ & $\begin{array}{l}\text { Application of FYM @ } 5 \text { t/ha enriched with Trichoderma @ } \\
2 \mathrm{~kg} / \text { tones of manure }\end{array}$ & $15.7(1.210)$ & 68.8 & 58.9 & 79.0 & 3.8 & 259.5 \\
\hline $\mathbf{T}_{2}$ & $\begin{array}{l}\text { Application of FYM @ } 5 \mathrm{t} / \mathrm{ha} \text { enriched with Azospirillum @ } \\
2 \mathrm{~kg} / \text { tones of manure }\end{array}$ & $20.0(1.316)$ & 60.2 & 82.5 & 70.6 & 4.2 & 396.2 \\
\hline $\mathbf{T}_{\mathbf{3}}$ & $\begin{array}{l}\text { Application of Vermicompost (VC) @ } 2.5 \mathrm{t} / \mathrm{ha} \text { enriched with } \\
\text { Trichoderma@2 kg/tones of manure }\end{array}$ & $13.3(1.145)$ & 73.5 & 46.8 & 83.3 & 3.5 & 299.2 \\
\hline $\mathbf{T}_{4}$ & $\begin{array}{l}\text { Application of Vermicompost (VC) @ } 2.5 \mathrm{t} / \mathrm{ha} \text { enriched with } \\
\text { Azospirillum @ } 2 \mathrm{~kg} / \text { tones of manure }\end{array}$ & $17.7(1.259)$ & 64.8 & 76.6 & 72.7 & 4.3 & 373.7 \\
\hline $\mathbf{T}_{\mathbf{5}}$ & $\begin{array}{l}\text { Application of FYM }\left(2.5 \mathrm{t} \mathrm{ha}^{-1}\right)+\mathrm{VC}\left(1.25 \mathrm{tha}^{-1}\right) \text { enriched } \\
\text { with Trichoderma @ } 2 \mathrm{~kg} / \text { tones of manure }\end{array}$ & $11.3(1.078)$ & 77.5 & 36.4 & 87.0 & 3.1 & 154.2 \\
\hline $\mathbf{T}_{6}$ & $\begin{array}{l}\text { Application of FYM }\left(2.5 \mathrm{t} \mathrm{ha}^{-1}\right)+\mathrm{VC}\left(1.25 \mathrm{tha}^{-1}\right) \text { enriched } \\
\text { with Azospirillum @ } 2 \mathrm{~kg} / \text { tones of manure }^{-}\end{array}$ & $18.3(1.288)$ & 63.6 & 67.1 & 76.1 & 3.6 & 354.5 \\
\hline $\mathbf{T}_{7}$ & $\begin{array}{l}\text { Application of FYM }\left(2.5 \mathrm{t} \mathrm{ha}^{-1}\right)+\mathrm{VC}\left(1.25 \mathrm{tha}^{-1}\right) \text { enriched } \\
\text { with Trichoderma }+ \text { Azospirillum @ } 2 \mathrm{~kg} / \text { tones of manure }\end{array}$ & $11.0(1.071)$ & 78.1 & 21.9 & 92.2 & 2.0 & 147.0 \\
\hline $\mathbf{T}_{8}$ & $\begin{array}{l}\text { Application of VC@ } 2.5 \text { t/ha enriched with Mycorrhizae } \\
\text { (Glomus intraradices) }\end{array}$ & $15.7(1.206)$ & 68.8 & 60.3 & 78.5 & 3.8 & 337.7 \\
\hline $\mathbf{T}_{9}$ & Application of $100 \%$ RDF & $10.3(1.057)$ & 79.5 & 28.5 & 89.8 & 2.7 & 151.3 \\
\hline $\mathbf{T}_{10}$ & Control (Non-infested with Striga) & $0.0(0.000)$ & 100.0 & 0.0 & 100.0 & 0.0 & 0.0 \\
\hline $\mathbf{T}_{11}$ & Control (infested with Striga) & $50.3(1.691)$ & 0 & 280.8 & 0 & 5.4 & 428.0 \\
\hline & $\begin{array}{l}\text { Mean } \\
\operatorname{LSD}(5 \%)\end{array}$ & $\begin{array}{r}16.7(1.120) \\
0.185\end{array}$ & & $\begin{array}{r}69.1 \\
79.278\end{array}$ & & $\begin{array}{r}3.3 \\
0.896\end{array}$ & $\begin{array}{l}263.8 \\
232.5\end{array}$ \\
\hline
\end{tabular}


Table.2 Yield and yield attributes of kodo millet as influenced by application of organic fertilizers and microbes.

\begin{tabular}{|c|c|c|c|c|c|c|c|c|c|}
\hline Code & Treatment details & $\begin{array}{l}\text { Plant } \\
\text { heigh } \\
\text { t } \\
(\mathrm{cm})\end{array}$ & $\begin{array}{l}\text { Leaves } \\
\text { plant }^{-1}\end{array}$ & $\begin{array}{l}\text { Leaf } \\
\text { area } \\
\left(\mathrm{cm}^{2}\right)\end{array}$ & $\begin{array}{l}\text { Panicle } \\
\text { weight }^{-1} \\
\text { plant }^{-1} \\
\text { (g) }\end{array}$ & $\begin{array}{l}\text { Fresh } \\
\text { weight } \\
\text { of plant } \\
\quad \text { (g) }\end{array}$ & $\begin{array}{c}\text { Dry } \\
\text { weight } \\
\text { of } \\
\text { plant } \\
\text { (g) }\end{array}$ & $\begin{array}{l}\text { Grain } \\
\text { yield } \\
\text { Kg ha }^{-1}\end{array}$ & $\begin{array}{c}\text { Grain } \\
\text { yield } \\
\text { increment } \\
\text { over } \\
\text { control } \\
(\%)\end{array}$ \\
\hline $\mathbf{T}_{1}$ & $\begin{array}{l}\text { Application of FYM @ } 5 \mathrm{t} / \mathrm{ha} \text { enriched with } \\
\text { Trichoderma@2 kg/tones of manure }\end{array}$ & 42.3 & 14.4 & 18.1 & 3.92 & 6.51 & 3.42 & 774.1 & 16.8 \\
\hline $\mathbf{T}_{2}$ & $\begin{array}{l}\text { Application of FYM @ } 5 \mathrm{t} / \mathrm{ha} \text { enriched with } \\
\text { Azospirillum @ } 2 \mathrm{~kg} / \mathrm{tones} \text { of manure }\end{array}$ & 43.0 & 15.0 & 19.0 & 3.84 & 6.34 & 3.23 & 763.0 & 15.1 \\
\hline $\mathbf{T}_{3}$ & $\begin{array}{l}\text { Application of Vermicompost (VC) @ } 2.5 \mathrm{t} / \mathrm{ha} \\
\text { enriched with Trichoderma @ } 2 \mathrm{~kg} / \text { tones of manure }\end{array}$ & 43.5 & 14.7 & 20.1 & 4.32 & 7.04 & 3.87 & 814.8 & 22.9 \\
\hline $\mathbf{T}_{4}$ & $\begin{array}{l}\text { Application of Vermicompost (VC) @ } 2.5 \mathrm{t} / \mathrm{ha} \\
\text { enriched with Azospirillum @ } 2 \mathrm{~kg} / \mathrm{tones} \text { of manure }\end{array}$ & 41.5 & 15.2 & 20.7 & 3.89 & 7.12 & 4.02 & 755.5 & 14.0 \\
\hline $\mathbf{T}_{5}$ & $\begin{array}{l}\text { Application of FYM }\left(2.5 \mathrm{t} \mathrm{ha}^{-1}\right)+\mathrm{VC}\left(1.25 \mathrm{t} \mathrm{ha}^{-1}\right) \\
\text { enriched with Trichoderma @ } 2 \mathrm{~kg} / \text { tones of manure }\end{array}$ & 46.1 & 17.9 & 23.7 & 4.82 & 7.58 & 4.37 & 888.9 & 34.1 \\
\hline $\mathbf{T}_{6}$ & $\begin{array}{l}\text { Application of FYM }\left(2.5 \mathrm{t} \mathrm{ha}^{-1}\right)+\mathrm{VC}\left(1.25 \mathrm{t} \mathrm{ha}^{-1}\right) \\
\text { enriched with Azospirillum @ } 2 \mathrm{~kg} / \text { tones of manure }\end{array}$ & 43.3 & 18.4 & 23.0 & 4.13 & 6.97 & 3.84 & 896.3 & 35.2 \\
\hline $\mathbf{T}_{7}$ & $\begin{array}{l}\text { Application of FYM }\left(2.5 \mathrm{tha}^{-1}\right)+\mathrm{VC}\left(1.25 \mathrm{t} \mathrm{ha}^{-1}\right) \\
\text { enriched with Trichoderma }+ \text { Azospirillum @ } 2 \\
\mathrm{~kg} / \text { tones of manure }\end{array}$ & 46.5 & 18.6 & 24.5 & 4.71 & 8.07 & 4.64 & 1022.2 & 54.2 \\
\hline $\mathbf{T}_{8}$ & $\begin{array}{l}\text { Application of VC@ } 2.5 \mathrm{t} / \text { ha enriched with } \\
\text { Mycorrhizae (Glomus intraradices) }\end{array}$ & 44.3 & 17.0 & 21.4 & 3.94 & 7.48 & 4.38 & 803.7 & 21.2 \\
\hline $\mathbf{T}_{9}$ & Application of $100 \%$ RDF & 47.5 & 17.8 & 24.6 & 4.36 & 7.69 & 4.63 & 1014.8 & 53.1 \\
\hline $\mathbf{T}_{10}$ & Control (Non-infested with Striga) & 38.9 & 13.2 & 17.8 & 3.36 & 6.02 & 2.97 & 748.1 & 12.8 \\
\hline $\mathbf{T}_{11}$ & Control (infested with Striga) & 36.7 & 11.7 & 16.8 & 3.02 & 5.02 & 2.79 & 663.0 & 0.0 \\
\hline & $\begin{array}{l}\text { Mean } \\
\operatorname{LSD}(5 \%)\end{array}$ & $\begin{array}{r}43.0 \\
5.462\end{array}$ & $\begin{array}{r}15.5 \\
2.611\end{array}$ & $\begin{array}{r}20.9 \\
3.632\end{array}$ & $\begin{array}{r}4.03 \\
0.586\end{array}$ & $\begin{array}{r}6.90 \\
0.656\end{array}$ & $\begin{array}{r}3.83 \\
0.684\end{array}$ & $\begin{array}{r}831.3 \\
218.48\end{array}$ & \\
\hline
\end{tabular}


It is concluded that soil application of FYM $\left(2.5 \mathrm{t} \mathrm{ha}^{-1}\right)+\mathrm{VC}\left(1.25 \mathrm{tha}^{-1}\right)$ enriched with Trichoderma+Azospirillum @ 2 kg/tones of manure and soil application of FYM (2.5 $\left.\mathrm{t} \mathrm{ha}{ }^{-1}\right)+\mathrm{VC}\left(1.25 \mathrm{t} \mathrm{ha}^{-1}\right)$ enriched with Trichoderma@2 kg/tones of manure before sowing were at par and found best for minimizing the infestation of Striga asiatica and obtaining maximum grain yield in kodo millet.

\section{Acknowledgements}

The authors are thankful to the ICAR and Project Coordinator (Small millets), Bangalore for providing the financial assistance and facilities under AICRP on small millets, College of Agriculture, Rewa (M.P.) for conducting the experiments. Also sincere thanks to the authorities of JNKVV, Jabalpur and College of Agriculture, Rewa (M.P.) for giving facilities and encouragement during the course of present investigation.

\section{References}

Abdel kader, M.M. and EI-Mougy, N.S. (2009). Prospects of mycoherbicides for control of Broomrape (Orobanche spp.) in Egypt. Journal of Plant Protection Research. 1: 63-65.

Boari,A., Ciasca, B., Pineda-Martos, R., Latttanzio, V.M., Yoneyama, K. and Vurro, M. (2016). Parasitic weed management by using strigolactone degrading fungi. Pest Management Science. doi:10.1002/ps.4226

Dzomeku, I.K. and Amegbor, I.K. (2013) Effect of organic manure and neem seed powder on Striga hermonthica control in maize in the Guinea savannah zones of Ghana. International Journal of Science and Nature. 4(4): 673-682

Esilaba, A.O., Reda, F., Ranson, J.K., Bayu, W.,Woldewahid, G. and Zemichael, B. (2000). Integrated nutrient management strategies for soil fertility improvement and Striga control in Northern Ethiopia. African Crop Science Journal.8(4):403410

Gacheru, E and Rao, M.R. (2001). Managing Striga infestation on maize using organic and inorganic nutrient sources in Western Kenya. International Journal of Pest Management. 47:233239

Gworgwor, N.A. and Weber, H.C. (2003). Arbuscular mycorrhizal fungi-parasitehost interaction for the control of Striga hermonthica (Del.) Benth. in sorghum (Sorghum bicolour (L) Moench.). Mycorrhiza. 13:277

Hassan, M.M., Doffalla, H.M., Modwi, H.I., Osman, M.G., Ahmed, I.I., Abdel Gani, M.E. and Babiker, A.G.E. (2013).Effects of fungal strains on seeds germination of millet and Striga hermonthica. Universal Journal of Agricultural Research. 2(2): 83-88

Haussman, B.I.G., Hess, D.E., Welz, H.G. and Geiger, H.H. (2000). Improved methodologies for breeding Striga resistant sorghums. Field Crops Research. 66: 195-211

Jain, A.K. and Tripathi, S.K. (2002). Occurrence of Striga and its influence on yield of kodo millet. Crop Research. 23(3): 532-535

Jain, A. K., Joshi, R. P. and Chauhan, S. S. (2016). Prevalence of Striga spp. in farmers field and host plant resistance in kodo millet against Striga asiatica (L.) Kuntze. JNKVV Res. J. 50(1): 52-55

Jain, A. K., Chourasia, Ruchi, Kumar, A. and Joshi, R. P. (2018). Identification of resistant genotypes against Striga asiatica (L.) Kuntze in kodo millet. Electronic Journal of Plant Breeding. 9(2):603-610

Kumar, L.S.S. (1940). Flowering plants which attack economic crops. I. Striga. Indian Farming. 1: 541. 
Kumar, L.S.S. and Soloman, S. (1941).A list of phanerogamic root parasite attacking economic crop in India. Proceeding Indian Academic Science B. 13:151-156

Lendzemo, V.W., Kuyper, Th.W., Kropff, M.J. and Ast, A.V. (2005). Field inoculation with arbuscular mycorrhizal fungi reduces Striga hermonthica performance on cereal crops and has the potential to contribute to integrated Striga management. Field Crops Research. 91:51-61

Osman, A.G., Hassan, M.M., Rugheim, A.M.E., Abdelgani, M.E. and Babiker, K.E. (2013). Effects of organic and microbial fertilizers on Striga hermonthica in maize. Universal Journal of Agricultural Research. 1(2):24-29

Othira, J.O., Omolo, J.O., Wachira, F.N. and Onek, L.A. (2012). Effectiveness of arbuscular mycorrhizal fungi in protection of maize (Zea mays L.) against witch weed (Striga hermonthica Del. Benth.) infestation. Journal of Agricultural Biotechnology and
Sustainable Development. 4(3):37-44

Porwal, B. L. (1975). An effective control of Striga in Bajra on farmers field. Annals of Arid Zone. 14(1): 45-48.

Reddy, P.L. and Dastagiraiah, P. (1987). Preliminary screening of kodo millet varieties against witch weed. Millets Newsletter. 6:57

Rodenburga, J., Bastiaansa, L., Weltzienb, E. and Hess, D.E. (2005). How can field selection for Striga resistance and tolerance in sorghum be improved?. Field Crops Research. 93(1):34-50

Sarmiso, Z. (2016). Effect of nitrogen fertilizer on Striga infestation, yield and yield related traits in sorghum (Sorghum bicolour (L) Moench) varieties at Kile, Eastern Ethiopia. Journal of Biology, Agriculture and Healthcare. 6(2):74-89

Srinivasan, A. R. (1947). Some new hosts for Striga. Current Science. 10:320-321

Teka, H.B. (2014) Advance research on Striga control; A review. African Journal of Plant Science. 8 (11): 492506.

\section{How to cite this article:}

Ruchi Chourasia and Jain, A.K. 2020. Effect of Organic Manures and Microbes on Striga asiatica (L.) Kuntze Management in Kodo Millet. Int.J.Curr.Microbiol.App.Sci. 9(08): 23572364. doi: https://doi.org/10.20546/ijcmas.2020.908.270 